Jurnal Pengabdian kepada Masyarakat

\title{
Menciptakan Teknopreneur Muda Bidang Jasa Service R-HVAC Di Politeknik Negeri Indramayu
}

\author{
Yudhy Kurniawan ${ }^{1}$, Wardika ${ }^{2 *}$ \\ ${ }^{1,2}$ Politeknik Negeri Indramayu, Jl. Raya Loh Bener Lama, No. 8, Kabupaten Indramayu \\ *yudhy@polindra.ac.id
}

\begin{abstract}
Kata Kunci:
Teknopreneur, jasa service RHVAC

Abstrak. Berdasar data dari BPS Kabupaten Indramayu, Pengangguran di Indramayu masih terbilang cukup tinggi, ada sekitar 9,21\% kenaikan tingkat pengangguran terbuka, dibanding tahun-tahun sebelumnya, bahkan dengan kondisi pandemic, diprediksi terjadi kenaikan lagi yang lebih signifikan. Menjawab permasalahan penting di atas, perlu ada upaya konkrit institusi Politeknik Negeri Indramayu (POLINDRA) dalam mewujudkan Tri Darma Perguruan Tinggi yaitu kegiatan pengabdian kepada masyarakat (PKM), dalam hal ini mengadakan program kewirausahaan bagi lulusan Polindra dengan menciptakan unit usaha jasa service bidang Pendingin dan Tata Udara (R-HVAC) untuk membantu mengatasi pengangguran tenaga kerja produktif. Tujuan dari PKM ini untuk menghasilkan teknopreneur muda terdidik berkompeten di bidang pendingin yang mampu bekerja secara mandiri dalam rangka meningkatkan taraf hidup serta menurunkan jumlah pengangguran usia produktif khususnya di wilayah Kabupaten Indramayu. Hasil yang dicapai dari program ini masih terdapat kendala penurunan minat peserta dari 5 orang menjadi 1 orang yang mestinya di targetkan minimal 2 wirausahawan, namun solusi yang dilakukan dengan penambahan 2 peserta lulusan dari sekolah lain. Sedangkan dari sisi penerapan softskill dan hardskill pada peserta yang tersisa terdapat peningkatan dari yang hanya sebatas penanganan satu unit mesin pendingin, kini sudah mampu mengerjakan unit-unit mesin pendingin yang lain.
\end{abstract}

Keywords:

Technopreneur; service work in the field of $R$ HVAC

\begin{abstract}
Based on data from BPS Indramayu Regency, Unemployment in Indramayu is still quite high, there is about a $9.21 \%$ increase in the open unemployment rate, compared to previous years, even with pandemic conditions, it is predicted that there is a more significant increase. Answering the important problem above, there needs to be concrete efforts of Polytechnic State of Indramayu (POLINDRA) in realizing Tri Darma Perguruan Tinggi, namely Community Service Activities (PKM), in this case conducting an entrepreneurial program for Polindra graduates by creating a service unit in the field of Refrigerating and Air Conditioning (R-HVAC) to help overcome productive labor unemployment. The purpose of this PKM is to produce competent young educated technopreneurs in the field of R-HVAC who are able to work independently in order to improve the standard of living and reduce the number of unemployed productive age, especially in the Indramayu regency. The results achieved from this program still have the constraints of decreasing the interest of participants from 5 person to 1 person who should be targeted at least 2 entrepreneur, but the solution is done with the addition of 2 graduate participants from other schools. While in terms of the application of softskill and hardskill to the remaining participants there is an increase from the only limited handling of one cooling machine unit, now it is able to work on other cooling machine units.
\end{abstract}




\section{PENDAHULUAN}

Berdirinya Politeknik Negeri Indramayu khususnya program studi Teknik Pendingin dan Tata Udara sebagai bagian dari kepedulian pemerintah kabupaten Indramayu menjawab kebutuhan lokal yang menjadi masalah krusial terutama permasalahan pengangguran kerja. Tuntutan kebutuhan ini secara luas berdampak pada terhambatnya perekonomian daerah, serta perubahan demografi penduduk yang kemudian sebagiannya mencari penghidupan diluar Indramayu. Keadaan ini oleh Badan Perencanaan Daerah (BAPEDA) meningkat dari tahun ketahun.

Tingkat pengangguran dan kemiskinan hingga saat ini merupakan masalah besar bangsa Indonesia yang belum bisa terpecahkan. Faktor-faktor yang menyebabkan terjadinya pengangguran di Indonesia, antara lain: Pertama, jumlah pencari kerja lebih besar dari jumlah peluang kerja yang tersedia (kesenjangan antara supply and demand). Kedua, kesenjangan antara kompetensi pencari kerja dengan kompetensi yang dibutuhkan oleh pasar kerja (mis-match), Ketiga, masih adanya anak putus sekolah dan lulus tidak melanjutkan yang tidak terserap dunia kerja/berusaha mandiri karena tidak memiliki keterampilan yang memadai (unskill labour), Keempat, terjadinya pemutusan hubungan kerja (PHK) karena krisis global, dan Kelima, terbatasnya sumber daya alam di kota yang tidak memungkinkan lagi warga masyarakat untuk mengolah sumber daya alam menjadi mata pencaharian. Dari kelima faktor tersebut, faktor pertama, kedua dan ketiga merupakan faktor dominan yang menyebabkan pengangguran di Indonesia (Permana, dkk, 2021).

Salah satu penanganan yang akan dilakukan terhadap masalah diatas dan sebagai wujud kepedulian pihak institusi perguruan tinggi dan kewajiban Tridarma bagi seorang dosen yaitu dengan memberikan mereka bekal keterampilan yaitu dengan kegiatan pemberdayaan kewirausahaan kepada lulusan mahasiswa yang memiliki minat dan kemauan berwirausaha khususnya dalam bidang pendingin dan tata udara (R-HVAC) sebagai bentuk implementasi keilmuan dan keahlian dibidang tersebut guna meningkatkan taraf hidupnya dijalur dunia usaha. Kesempatan program kewirausahaan ini mengingat di Indramayu masih minim tenaga terampil untuk menangani khususnya jasa service R-HVAC, terutama di domestik perumahan, perkantoran, dan hotel, swalayan, retail dan lain-lain yang rata-rata berlatar belakang bukan bidangnya, sementara kebutuhan terhadap jasa service bidang ini sangat besar. Dalam program PkM kewirausahaan ini diberikan pengetahuan dan ketrampilan teknik wawasan kewirausahaan dan etika kerja, serta pemahaman tentang penggunaan Refrigeran yang ramah lingkungan yaitu R32 (Polarin,2016), sesuai aturan baru yang tidak boleh lagi memproduksi R22 khususnya pada Air Conditioning (AC) (Permen Perdagangan RI. No. 84/M-DAG/PER/10/2015). Dalam kegiatan pengabdian ini sumber daya manusia yang mendukung program ini diupayakan melibatkan mahasiswa prodi teknik pendingin dan tata udara sebagai peserta kewirausahaan khususnya pada alumni mahasiswa jurusan Teknik Pendingin dan Tata Udara, sehingga saat mereka lulus nantinya sudah tidak merasa kuatir terhadap masalah pekerjaan dan memiliki pengalaman kewirausahaan secara mandiri yang kemudian dapat menciptakan lapangan kerja baru.

Kegiatan pengabdian kepada masyarakat pada kewirausahaan ini tidak hanya bertujuan untuk mengenalkan dan meningkatkan pengetahuan (knowlege), dan keterampilan (skill) khususnya bidang tata udara kepada masyarakat sehingga dapat beradaptasi dan bersaing sehat didunia usaha, namun juga secara softskill mencapai peningkatan kualitas sumberdaya manusia agar nantinya selain terlahir sebagai insan terdidik juga berkarakter mandiri, ulet, bekerja keras, pantang menyerah, bertanggungjawab, berani menanggung 
risiko, bermotif ekonomi, menghargai waktu dan memanfaatkan setiap kesempatan, produktif, kreatif dan inovatif (Santosa,2014), serta mampu menjalin hubungan kerjasama yang baik dengan pihak terkait yang konsern pada usaha ini, dan akhirnya duharapkan dapat mengurangi tingkat pengangguran di Kab. Indramayu.

\section{METODOLOGI}

Dalam kegiatan PkM Kewirausahaan ini dilakukan dengan beberapa tahapan yang digambarkan dalam alur kegiatan sebagai berikut:

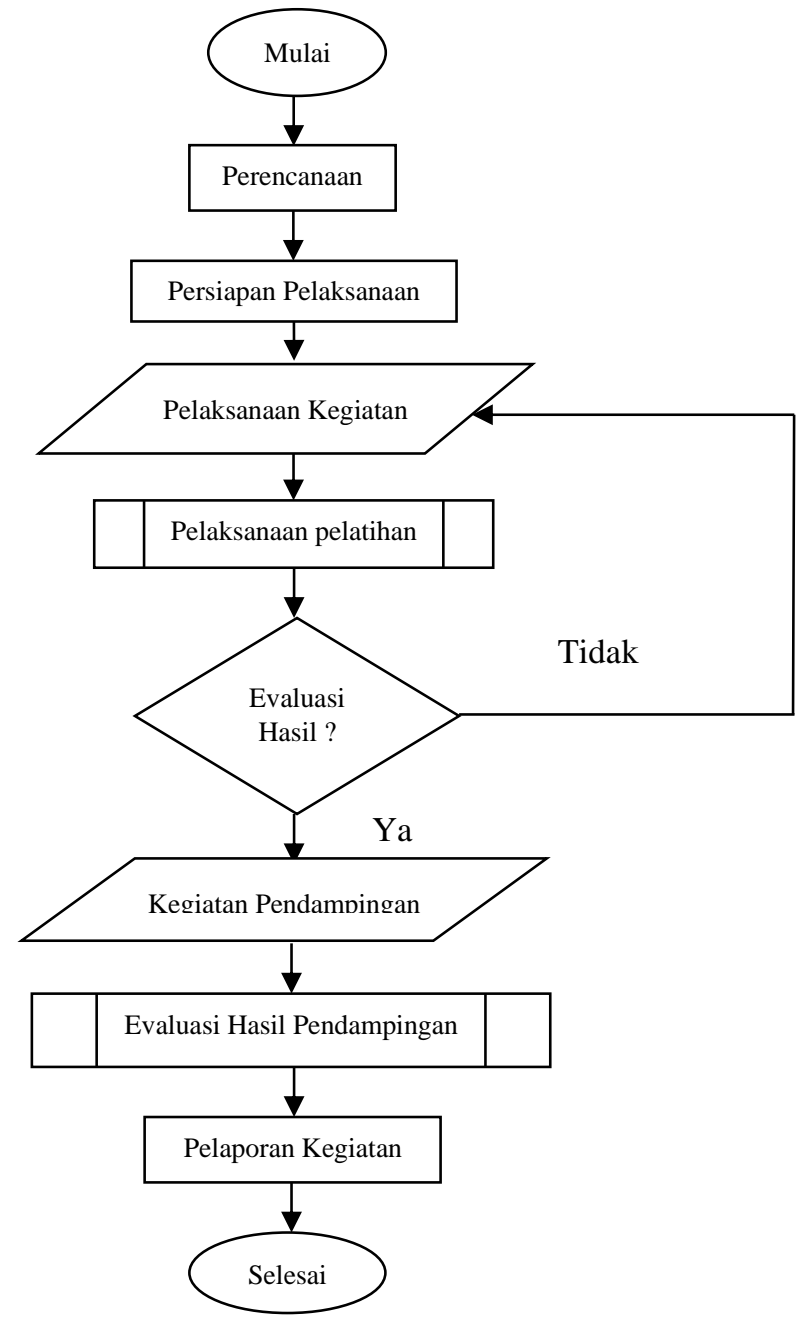

Gambar 1. Alur Kegiatan PkM Kewirausahaan

\subsection{Tahapan Perencanaan}

Pada tahapan ini dilakukan pekerjaan kordinasi dengan tim PkM terkait sosialisasi kegiatan, penentuan jadwal kegiatan, pembagian kerja, perencanaan rekruitmen mitra terutama lulusan dari jurusan teknik pendingin dan tata udara Polindra.

\subsection{Tahapan Persiapan Pelaksanaan}

Kegiatan dilanjutkan dengan tahapan persiapan berupa penyediaan fasilitas pelatihan keahlian dan wawasan kewirausahaan. Disamping itu pada tahapan ini dipersiapkan instruktur pelatihan dari unsur dosen dan teknisi dan penyiapan materi pembelajarannya. Untuk proses persiapan pelaksanaan dilakukan rekruitmen peserta berdasarkan minat dan kompetensinya yaitu penguasaan di bidang pendingin dan tata udara (R-HVAC), dimana 
pada kegiatan PkM kewirausahaan ini diambil calon peserta 5 orang terutama diprioritaskan dari alumni/ lulusan mahasiswa Jurusan Teknik Pendingin dan Tata Udara Polindra yang belum mendapatkan pekerjaan, dengan berkordinasi dengan pihak jurusan dan jaringan alumni polindra, dan dari 5 orang tersebut diharapkan tercipta minimal 2 wirausahawan sesuai keahliannya (technopreneur). Pola rekruitmen yang dilakukan berdasarkan pertimbangan kesesuaian bidang ilmu yang dalam hal ini memahami bidang pendingin dan tata udara, yaitu prinsip dasar dan sistem refrigerasi, perawatan dan servis mesin-mesin R-HVAC seperti AC dan Kulkas. Disamping itu pendekatan wawancara mengenai sejauh mana motivasi dan kemauan dalam menjalankan usaha di bidangnya (technopreneurship), setelah itu dibuatkan surat pernyataan kesediaan sebagai komitmen kerjasama.

\subsection{Tahapan Pelaksanaan}

Pada tahapan ini ada beberapa rincian kegiatan yang dilakukan sebagai berikut :

\subsubsection{Pelaksanaan Pembekalan/Pelatihan}

Pelaksanaan pelatihan keahlian dan wawasan teknopreneur di Ruang Kelas dan Bengkel Teknik Pendingin dan Tata Udara POLINDRA, dimana waktu pelaksanaannya dilakukan pada masa liburan kuliah sehingga tidak mengganggu jadwal proses belajar mengajar. Dalam pelatihan ini hal-hal yang dipersiapkan adalah :

a. Pembuatan jadwal pelatihan selama 4 hari.

b. Mengatur instruktur/tenaga pengajar yang bertugas.

c. Menyediakan media pengajaran.

d. Pembuatan handout / Jobsheet materi.

e. Pelaksanaan pelatihan teori dan praktek total selama 15 jam tatap muka.

\subsubsection{Tahapan Evaluasi Kegiatan Pembekalan}

Pada tahapan ini merupakan kegiatan evaluasi untuk mengukur sejauhmana pengetahuan dan pemahaman peserta setelah mengikuti pelatihan, dimana kegiatan yang dilakukan adalah sebagai berikut :

a. Evaluasi teori dilaksanakan dengan test lisan pada akhir pelaksanaan pembelajaran teori.

b. Evaluasi praktek dilaksanakan dengan observasi dan wawancara, dilaksanakan pada saat sedang praktek maupun akhir praktek

c. Evaluasi kegiatan pelatihan, dilaksanakan oleh tim pelaksana PkM dibantu instruktur/teknisi Jurusan Teknik Pendingin dan Tata Udara

\subsubsection{Tahapan Proses Pendampingan}

Tahapan pendampingan dilakukan kepada para peserta yang sudah mengikuti proses pembekalan, dengan dimonitor dan diawasi langsung dari tim pelaksana PkM secara berkala. Pola kordinasi dilakukan dengan menunjuk kepala pelaksana dari salah seorang peserta dengan dijelaskan tupoksi dan kewenangan pekerjaannya. Ditahapan ini tim pelaksana PkM memberikan fasilitas kepada peserta berupa pengadaan alat dan bahan service, tempat usaha, termasuk biaya transportasi survey, dengan mengajukan rencana anggaran dan kebutuhan. Untuk survey lokasi kegiatan kewirausahaan yang perlu diperhatikan terkait segmenting, teargetting, dan positioning yang strategis. Sedangkan untuk proses pendampingan, bimbingan teknis yang diberikan kepada peserta berupa aspek manajemen dan aspek teknis. Pada kegiatan pengawasan, peserta akan dievaluasi terkait manajemen aktivitasnya, kinerjanya, dan perkembangan usaha yang dijalankan secara berkala (Tim Polindra, 2012). 


\subsubsection{Pelaporan hasil pendampingan kewirausahaan}

Tahapan pelaporan, peserta diminta membuatkan laporan secara tertulis dan lisan dengan menunjukan bukti laporan pekanan, baik laporan kegiatan dan keuangannya. Termasuk berbagai peluang dan hambatan yang dihadapi saat menjalankan usaha tersebut.

\section{HASIL DAN PEMBAHASAN}

\subsection{Tahapan Rekruitmen}

Pada kegiatan rekruitmen yang diselenggarakan tanggal 26 Maret 2021 didapatkan peserta yang sesuai dengan kualifikasi ada 5 orang, dimana semuanya merupakan alumni mahasiswa D3 Jurusan Teknik Pendingin dan Tata Udara POLINDRA. Dari 5 orang ini diharapkan minimal ada 2 orang yang sukses menjadi wirausawan mandiri, sesuai dengan luaran dari kegiatan PkM Kewirausahaan ini. Untuk tim rekruitmen dilakukan oleh tim peneliti dibantu oleh tenaga admin dan teknisi. Dari kegiatan tersebut sekaligus dilakukan sosialisasi terkait program PkM Kewirausahaan yang mana diberikan penjelasan tentang tujuan dan manfaat dari program, alur kegiatan program, serta fasilitas yang diberikan selama mengikuti program tersebut (lihat pada gambar 2).
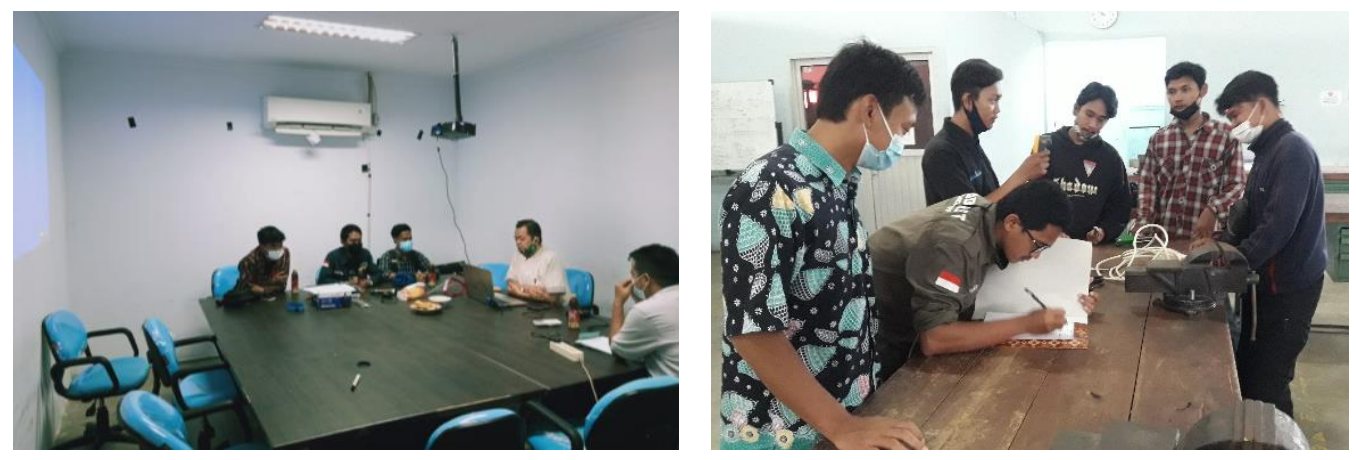

Gambar 2. Proses Sosialisasi dan Rekruitmen

\subsection{Tahapan Pembekalan/Pelatihan}

Pada tahapan ini peserta diberikan informasi tentang jadwal kegiatan pelatihan yang diadakan di kampus Jurusan Teknik Pendingin dan Tata Udara POLINDRA (lihat di tabel 1), pelatihan diberikan terkait dengan materi penguatan kompetensi, dan wawasan kewirausahaan, etika kerja yang selama ini tidak dikembangkan di bangku kuliah. Metode pembelajaran dilakukan secara interaktif berupa diskusi dan Tanya jawab kepada peserta. Pelatihan ini dilengkapi dengan sarana penunjang alat dan bahan untuk kegiatan praktek yang secara praktis sering digunakan dalam kegiatan service dibidang pendingin dan tata udara (R-HVAC) disektor domestik, seperti praktek service dan perawatan AC dan Kulkas/showcase, termasuk instalasi pemasangan AC, pengisian refrijeran, control dan kelistrikan yang selama ini dibutuhkan custumer (lihat gambar 3). 
Berikut ini adalah rincian jadwal kegiatan pelatihan:

Tabel 1. Jadwal Kegiatan Pelatihan

\begin{tabular}{|c|c|c|c|c|c|}
\hline JAM & WAKTU & $\begin{array}{c}\text { SENIN } \\
\text { (29 } \text { Maret 2021) }\end{array}$ & $\begin{array}{c}\text { SELASA } \\
\text { (30 Maret 2021) }\end{array}$ & $\begin{array}{c}\text { RABU } \\
\text { (31 Maret 2021) }\end{array}$ & $\begin{array}{c}\text { KAMIS } \\
\text { (01 April 2021) }\end{array}$ \\
\hline 1 & $07.00-08.00$ & \multirow{3}{*}{$\begin{array}{c}\text { Soft skill \& K3 } \\
\text { Pemateri : Wardika } \\
\text { (Ruang Kelas) }\end{array}$} & \multirow{3}{*}{$\begin{array}{c}\text { Wawasan } \\
\text { Teknopreneur dan } \\
\text { Etika Kerja } \\
\text { Pemateri: Yudhy } \\
\text { Kurniawan } \\
\text { (Ruang Kelas) } \\
\end{array}$} & \multirow{3}{*}{$\begin{array}{c}\text { Praktek Perawatan } \\
\text { Pemateri : Hadi } \\
\text { Priyatno } \\
\text { (Bengkel TPTU) }\end{array}$} & \multirow{3}{*}{$\begin{array}{c}\text { Evaluasi Ujian } \\
\text { Teori } \\
\text { (Tim PkM) } \\
\text { Ruang Dosen } \\
\text { TPTU } \\
\end{array}$} \\
\hline 2 & $08.00-09.00$ & & & & \\
\hline & & & & & \\
\hline 3 & $09.00-09.15$ & \multicolumn{4}{|c|}{ Coffe Break } \\
\hline 4 & $09.15-10.15$ & \multirow{3}{*}{$\begin{array}{c}\text { Perawatan Mesin } \\
\text { Tata Udara } \\
\text { Pemateri: Yudhy } \\
\text { Kurniawan } \\
\text { (Ruang Kelas) } \\
\end{array}$} & \multirow{3}{*}{$\begin{array}{c}\text { Perawatan Mesin } \\
\text { Refrigerasi } \\
\text { Pemateri : Wardika } \\
\text { (Ruang Kelas) }\end{array}$} & \multirow{3}{*}{$\begin{array}{c}\text { Praktek } \\
\text { Troubleshooting } \\
\text { Pemateri : Hadi } \\
\text { Priyatno } \\
\text { (Bengkel TPTU) }\end{array}$} & \multirow{3}{*}{$\begin{array}{c}\text { Evaluasi } \\
\text { Ujian Praktek } \\
\text { (Tim PkM) } \\
\text { Bengkel TPTU }\end{array}$} \\
\hline 5 & $10.15-11.15$ & & & & \\
\hline 6 & $11.15-12.15$ & & & & \\
\hline
\end{tabular}

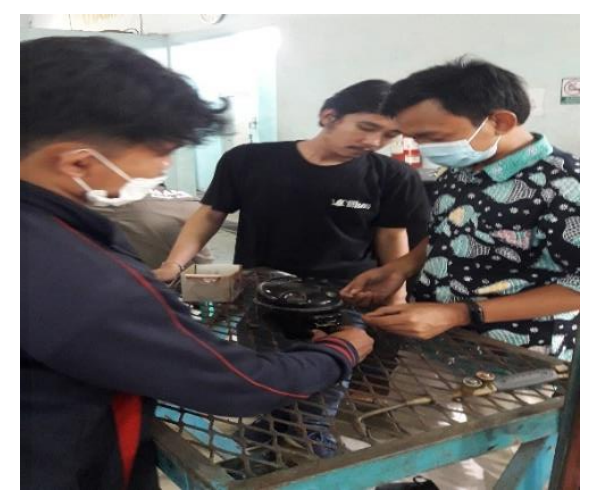

Gambar 3. Kegiatan Pembekalan Praktek Mesin Pendingin

Kegiatan pembekalan/pelatihan ini dilaksanakan selama 4 hari (20 jam pertemuan), dimana diakhir pelatihan peserta akan dievaluasi dan diuji sesuai dengan bekal pelatihan yang sudah mereka dapatkan. Metode yang dilakukan dengan cara diskusi dan interview langsung, serta observasi terkait kegiatan ujian prakteknya (lihat gambar 4 dan 5). Dari hasil evaluasi peserta mengikuti kegiatan pelatihan dengan baik dalam hal penguasaan pengetahuan, keterampilan dan wawasan baik teoritis maupun praktek.

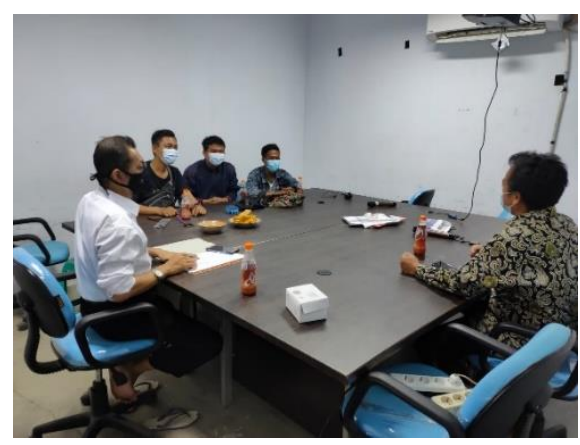

Gambar 4. Evaluasi Hasil Pembekalan 

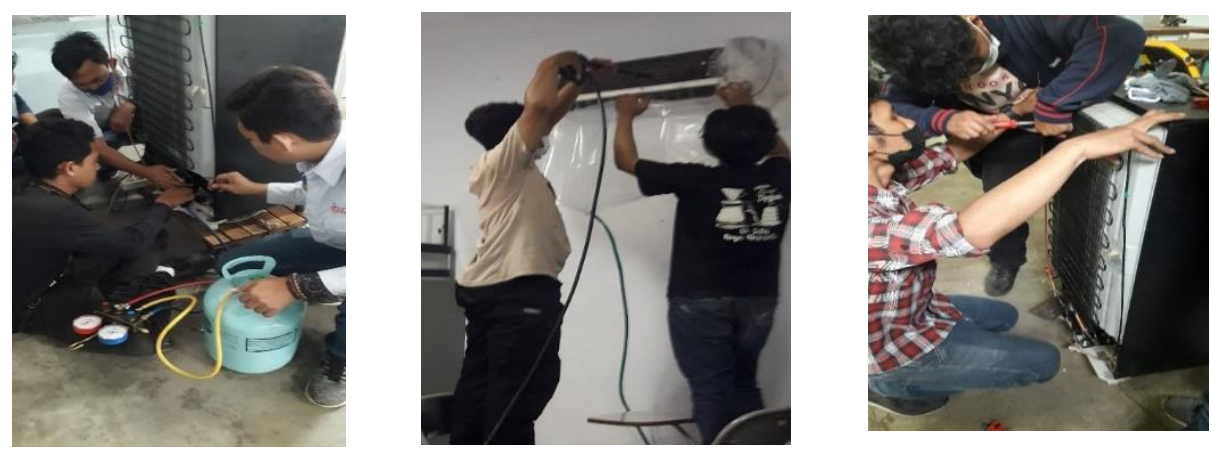

Gambar 5. Ujian Praktek Service Mesin Pendingin

\subsection{Tahapan Pelaksanaan Kewirausahaan}

Setelah peserta mendapatkan pembekalan/pelatihan dari tim PkM Kewirausahaan, selanjutnya diberikan pelatihan kesempatan berwirausaha dengan membentuk tim kerja, dimana pada tim ini ditunjuk kordinator tim. Tugasnya adalah mengorganisasikan kegiatan wirausaha dibidang jasa service mesin pendingin dan pengkondisian udara. Mereka dibekali dengan fasilitas alat-alat service dan tempat kegiatan kewirausahaan yang didapat dengan mengontrak selama program PkM berjalan. Tempat tersebut dicarikan di lokasi yang cukup strategis berada di kawasan kota Indramayu yaitu di Perumahan Graha Panyindangan Estate No.15A Kec.sindang, Kab. Indramayu (Lihat Gambar 8).

Untuk menawarkan usaha jasa service tersebut maka diarahkan para peserta untuk membuat brosur atau pamflet sebagai media informasi dan promosi usaha, kemudian disebarkan ke relasi-ralasi termasuk memanfaatkan networking (jaringan) di masyarakat daerah sekitar tempat usaha, ini yang menjadi salah satu kunci sukses bagi wirausahawan (Madani, 2017), termasuk memanfaatkan penyebaran informasi yang dilakukan melalui media sosial yang ada seperti tersaji dalam Gambar 6 .

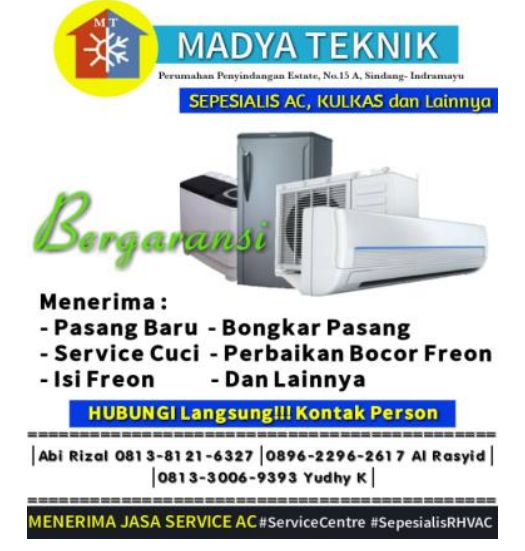

Gambar 6. Contoh Brosur/Pamflet 


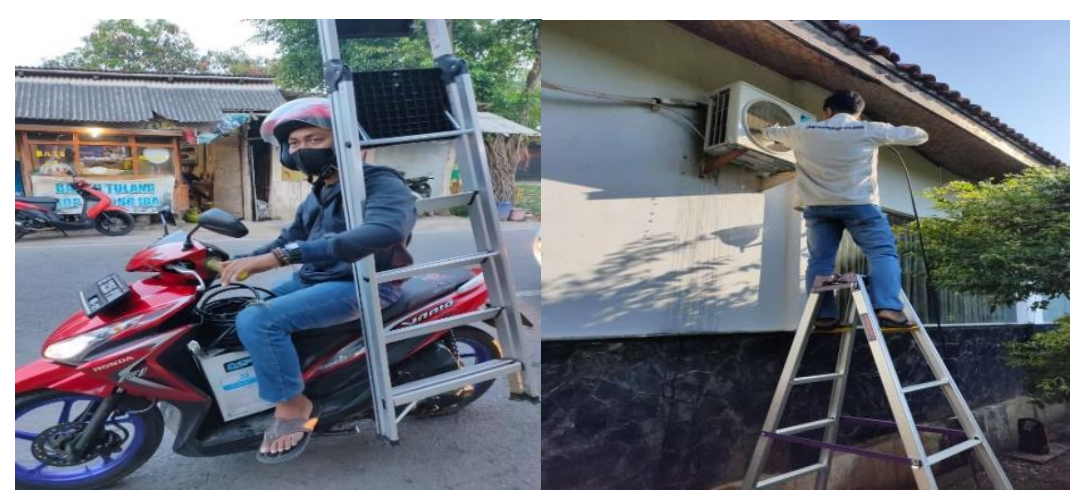

Gambar 7. Kegiatan Service Mesin-mesin Pendingin

Setelah menawarkan usaha tersebut, kegiatan usaha jasa service ini mulai berjalan dari bulan April 2021 dimana, setiap pekannya mengerjakan project service rata-rata sebanyak 4 atau 5 tempat, dan dalam 1 tempat mengerjakan lebih dari 1 unit. Dimana pekerjaan service bisa dilaksanakan di tempat customer, atau jika dibutuhkan penanganan perbaikan serius, dikerjakan di tempat usaha, atau di bengkel Jurusan Teknik Pendingin dan Tata Udara, Polindra. Pekerjaan service lebih banyak dilakukan di area kota Indramayu, walau ada yang meminta untuk pekerjaan service di daerah Cirebon, seperti di PT. Catur Sentosa Abadi.

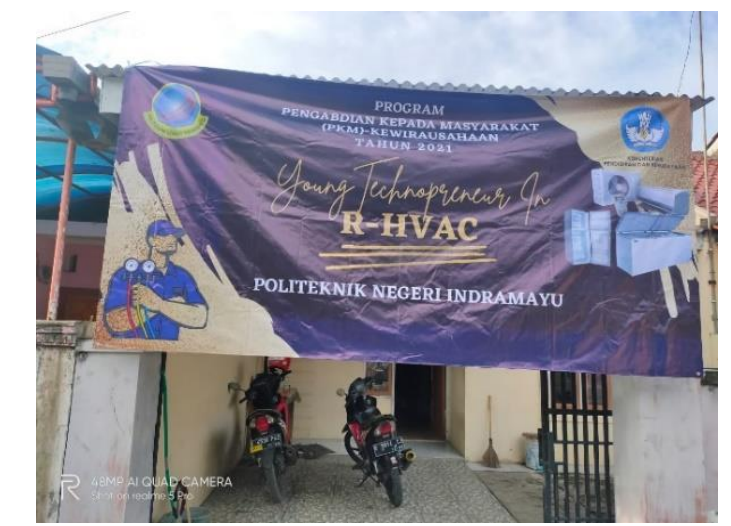

Gambar 8. Tempat Kegiatan Kewirausahaan

\subsection{Tahapan Pendampingan Usaha}

Kegiatannya berupa konsultasi dari peserta, monitoring dan pelaporan kegiatan. Kegiatan ini dilakukan di tempat mitra, tempat peserta menjalankan usahanya, atau diadakan di kampus, ruang rapat jurusan Teknik Pendingin dan Tata Udara. Pada saat pendampingan, tim PkM meminta kepada peserta menyampaikan keluhan atau kendala selama menjalankan usahanya (LIhat gambar 9). 

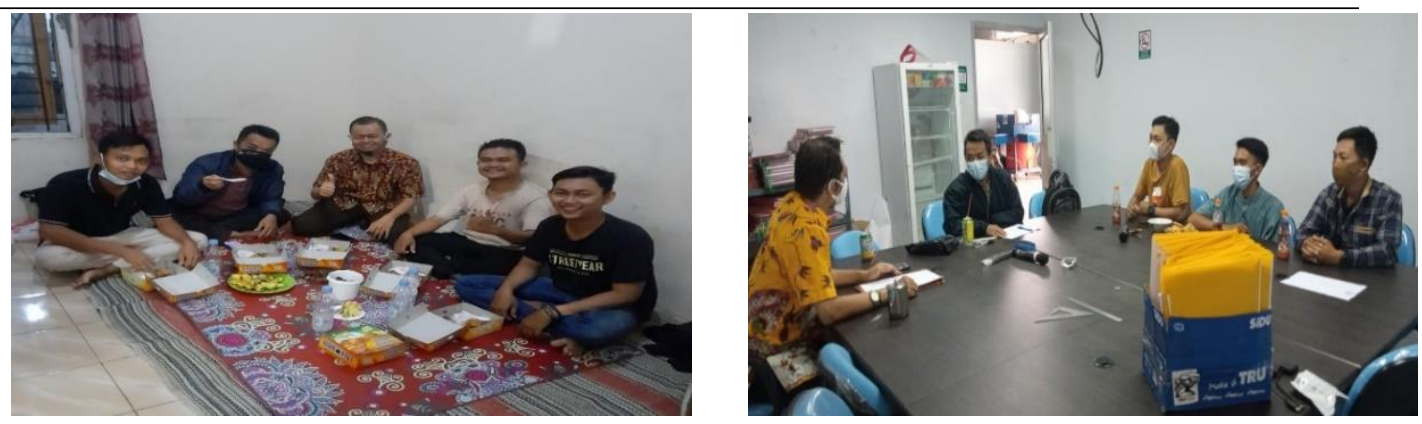

Gambar 9. Proses Pendampingan Peserta

Kendala dan permasalahan yang dihadapi selama kegiatan pelaksanaan kewirausahaan adalah sebagai berikut:

1. Kurangnya komunikasi aktif dari peserta kewirausahaan dilapangan, terutama terkait permasalahan teknis;

2. Adanya rangkap kegiatan usaha lain dari peserta, sehingga menjadi kurang fokus, dan kurang terorganisasi dengan baik;

3. Masih rendahnya komitmen dari peserta terkait dengan kegiatan yang sudah disepakati bersama.

4. Masih belum banyaknya jaringan mitra usaha.

Akibat kendala tersebut, beberapa peserta mengundurkan diri dengan alasan diterima bekerja ditempat lain dan sibuk dengan usahanya yang lain, sehingga peserta yang ada dari 5 peserta tinggal 1 orang. Sebagai langkah solusi bahwa output yang ditargetkan menghasilkan minimal 2 peserta kewirausahaan belum tercapai, dilakukan dengan merekrut kembali peserta yang benar-benar memiliki kemauan untuk berwirausaha, terutama akses diberikan tidak hanya dari calon peserta dari alumni jurusan pendingin dan tata udara, namun dari lulusan sekolah menengah kejuruan yang berminat terhadap usaha ini. Dari progress rekruitmen calon peserta yang tertarik dan berminat untuk kegiatan kewirausahaan ini ada 2 orang (semua dari lulusan SMK yang berlokasi di Indramayu). Dari 2 orang peserta tadi kemudian diberikan pembekalan secara teknis dan praktis tentang perawatan dan service di bidang pendingin dan pengkondisian udara. Secara ekonomis income yang didapat memang belum dirasakan secara maksimal, karena lebih banyak yang ditangani projeknya berskala rumahan, namun dari modal yang diberikan secara stimulan dari program kegiatan PkM ini memberikan support terhadap kemauan dan pengalaman berwirausaha di bidang R-HVAC. Hasil jasa service yang diperoleh dari modal nol rupiah kemudian dapat dimanfaatkan income nya untuk peningkatan usaha tersebut. Dan secara sosial telah mengurangi nilai pengangguran masyarakat terdidik di Indramayu. Untuk hasil progress kompetensi keahlian sudah lebih meningkat, dimana peserta lebih banyak menangani projek unit pengkondisian udara (AC split) kini sudah bisa menangani unit mesin pendingin dan mesin elektronik lainnya, seperti mesin cuci, kulkas, showcase, dan lain sebagainya.

\section{KESIMPULAN}

Dari pelaksanaan program pengabdian kepada masyarakat untuk kewirausahaan di bidang R-HVAC dapat disimpulkan bahwa terdapat kendala yang terjadi pada pelaksanaan kewirausahaan sehingga berdampak pada penurunan minat peserta sebesar $80 \%$ terutama disebabkan alasan bekerja ditempat lain, dan focus pada usaha lain. Kegiatan jasa service masih didominasi skala domestic/rumahan, belum banyak menjangkau skala projek komersial. Sehingga income yang dihasilkan belum didapat 
penambahan secara signifikan. Secara kompetensi dari hasil kegiatan pembekalan ada peningkatan kompetensi atau keahlian dari hanya sekedar menangani AC split, kini sudah bisa menangani mesin-mesin pendingin yang lain. Termasuk peningkatan kemampuan softskill baik kemandirian dan kemampuan mengorganisir tim dalam bekerja, terbukti yang tadinya hanya menangani projek service sendiri, kini sudah punya asisten peserta yang mau terlibat dalam kegiatan usaha ini.

\section{UCAPAN TERIMA KASIH}

Sebagai Tim Pelaksana program PkM Kewirausahaan mengucapkan terimakasih yang sebesar-besarnya kepada Pusat Penelitian dan Pengabdian kepada Masyarakat (P3M) Politeknik Negeri Indramayu yang telah memberikan pendanaan Internal tahun 2021 untuk pelaksanaan PkM ini sehingga berjalan dengan semestinya. Serta tidak lupa pula mengucapkan kepada mitra peserta program atas kerjasama yang baik sehingga pelaksanaan PkM dapat diselesaikan dengan baik.

\section{Daftar Pustaka}

Permana, Asep Yudi. dkk. 2021. Pelatihan Technopreneur Calon Arsitek Dalam Membangun Jiwa Wirausaha. Lentera Karya Edukasi: Jurnal PKM. Vol. 1. No.1. April 2021. Pp. 16-24

Santosa, Imam. 2014. Masalah Dan Tantangan Pengembangan Kewirausahaan Pada Kalangan Mahasiswa Di Indonesia. Jurnal Inovasi dan Kewirausahaan volume 3 nomor 3 tahun 2014

Permen Perdagangan RI. No. 84/M-DAG/PER/10/2015. Ketentuan Impor Barang Berbasis Sistem Pendingin, pasal 1, ayat 2

Tim Polindra. 2012. Pelatihan Kecakapan Hidup Bidang Teknik. Jurusan Teknik Pendingin dan Tata Udara Politeknik Negeri Indramayu

Kementerian Pendidikan Nasional, Direktorat Jenderal Pendidikan Tinggi, 2010. Pedoman Program Mahasiswa Wirausaha

Kementrian Pendidikan Nasional, Direktorat Pembinaan Kursus dan Kelembagaan. 2010. Konsep Dasar Kewirausahaan

Madani, G. 2017. Menumbuhkan Wirausahawan Muda Indonesia dengan Pendidikan Kewirausahaan Terintegratif. www.kompasiana.com.

Polarin, 2016. 4 Keuntungan Penggunaan Refrigeran R32. https://polarin.co.id/

BPS Kab. Indramayu. Survey Angkatan Kerja Nasional. https://indramayukab.bps.go.id/indicator/6/101/1/tingkat-pengangguranterbuka.html 